\section{Mediaeval Archaeology}

Scientific Methods in Medieval Archaeology. Edited by Rainer Berger. Pp. xvii +459. (University of California: Berkeley, Los Angeles, and London, July 1971.) $£ 9.50$.

THE aim of this compendium of papers is to illustrate how scientific techniques might be used in research on mediaeval Europe and the Near East. The majority were presented at an international conference in 1967 which was attended by scientists, archaeologists and historians. The book is divided into two parts, devoted to dating and "tracing" methods respectively.

In part one, ten chapters are devoted to techniques relevant to the study of timbers from surviving mediaeval buildings in Europe. Radiocarbon dating is described and the possible reasons for the discrepancies between radiocarbon ages and true calendar ages, as determined by dendrochronology, are outlined. The radiocarbon dating results for a group of mediaeval buildings are discussed in detail, a lavish sequence of photographs and architectural drawings of the buildings being included. The principles of dendrochronology are presented and in addition the typological development of timber-framed buildings and timber roofs in England is described. The remaining four chapters deal with thermoluminescent dating of ceramics, archaeomagnetic dating of pottery kilns and tephrochronology (that is, the study of the layers of airborne ash produced by volcanic eruptions).

The six chapters in the second part are concerned principally with the description of various physical methods, such as neutron activation and X-ray fluorescence analysis, for the examination of archaeological artefacts. Discussion of the use of these methods for identifying the raw materials used in the manufacture of glass, glaze and metal artefacts, for establishing the source of the clay used for pottery and for elucidating the techniques used in the manufacture of Islamic glass is included. There are also chapters on the possible determination of the intensity of worldwide lead smelting, using lead aerosol deposits in polar snow strata, and on magnetic prospecting for the location of buried archaeological features.

The main criticism of this book is that the choice of topics results in a somewhat unbalanced picture of both mediaeval archaeology itself and of the application of science to archaeology. First, undue emphasis (approximately two-thirds of the book) is placed on the study of surviving timber buildings and the scientific methods for dating them. Second, there is no mention of those techniques (for example, petrological and metallographic microscopy) which are appropriate for the study of the development of ceramic and metal tech. nology. Third, no adequate discussion of the role of the biological sciences in providing information on the environment (for example, flora and fauna) and on man himself (for example, ages at death, prevalent diseases) is included.

Thus although the conference itself was undoubtedly valuable in that it brought together both scientists and archaeologists and served to emphasize the importance of scientific and archaeological techniques for supplementing the data obtained from written records from the mediaeval period, the conference proceedings, published in this book, are of considerably less value. The mediaeval archaeologist would therefore be better advised to purchase one of the more general books, now available, on the application of science to archaeology, especially considering the high price of this volume.

\section{S. Tite}

\section{Sperm Phylogeny}

Comparative Spermatology. Edited by Baccio Baccetti. (Proceedings of an International Symposium held in Rome and Siena, 1/5 July 1969.) Pp. 573. (Accademia Nazionale dei Lincei: Rome; Academic Press: New York and London, 1970.) $\$ 22.50 ; £ 10.50$.

THIs volume records the proceedings of an international symposium which was designed to bring together morphologists, histochemists and physiologists to attempt to correlate structure and function of spermatozoa and to examine the available information from a phylogenetic standpoint.

The book comprises, therefore, individual contributions from specialists from widely differing disciplines and, as one whose interests lie particularly with the interrelationships of sperm structure and function, $I$ found it of great interest to look at the subject through other eyes. I am left with little doubt that the symposium met a genuine need and that the book is a worthy record of its proceedings.

For taxonomists there is a wealth of information about the ultrastructure of spermatozoa of a wide range of invertebrate and vertebrate species with an important contribution by Irene Manton on plant spermatozoids. As an outsider, I was interested in her comments about the dangers of trying to extract from the evidence conclusions about phylogenetic relationships and of being trapped into absurdities "such as deriving lungfishes from mosses".

In addition to morphological and ultrastructural patterns a number of contributions are concerned with detailed studies of separate components and organelles. Among those receiving individual treatment are the acrosome, the nucleus, the flagellum, the connecting piece, the post-nuclear cap, microtubules and mitochondria.

Functional aspects of ultrastructure which are discussed include both motility and fertilizing capacity. There are several contributions which illustrate the very successful application of histochemical methods at the ultrastructural level.

The quality of the illustrations, which form such a large part of this book, will undoubtedly make for its success; and the transcript of the discussions which followed each paper is a valuable addition to the text.

With the reservation that the book caters for very specialized interests, I support the claim made for it that it will be of value to research workers in zoology, reproductive developmental biology, anatomy, biochemistry, medical research and botany. J. L. HANCOCK

\section{Microbes Against Pests}

Microbial Control of Insects and Mites. Edited by H. D. Burges and N. W. Hussey. Pp. xxii +861 . (Academic Press: London and New York, March 1971.) $£ 11.50$.

THE science of insect pathology has been a remarkably late developer. Born in the 1870 s with the work of Pasteur and Metchnikoff, it made (apart from the excellent work of Dutky and his associates on Bacillus popilliae) little real progress for the next seventy years. The 1950 s saw both a revival of interest and a necessary change of emphasis from empirical field trials of microorganisms for the control of insect pests to fundamental studies of the pathogens and their host-relationships. In 1963 Academic Press published a two-volume treatise entitled Insect Pathology, under the editorship of the late E. A. Steinhaus, which bore witness to the rapid progress engendered by the new approach. The same publishers have now brought out another major work in this field covering the developments of the past eight years.

The new book differs from its predecessor in being primarily concerned with the utilization of microorganisms for the purposes of pest control, but the importance of the biological background is fully recognized and much of the most interesting material is concerned with fundamental studies, particularly in the field of bacterial toxicology. The forty-three contributors who have collaborated in this work are acknowledged leaders in their fields and the contributions are, therefore, authoritative.

The uses of bacteria, viruses, fungi, 